\title{
Assessment of Quality of Life in Patients with Subacromial Impingement
}

\section{Subakromiyal Sıkışma Sendromlu Hastalarda Yaşam Kalitesinin Değerlendirilmesi}

\author{
๑Tuğçe Pasin'1, @Özge Pasin² \\ 'Department of Physical Medicine and Rehabilitation, Istanbul Goztepe Training and Research Hospital, Istanbul, Turkey \\ 2Department of Biostatistics, Faculty of Medicine, Istanbul University, Istanbul, Turkey
}

\begin{abstract}
Background: Evaluating the quality of life patients with subacromial impingement syndrome is important for further treatments.

Aim: The aim of the study was to evaluate simultaneously the quality of life with subacromial impingement syndrome using different parameters in a single model.

Material and Method: Ninety patients diagnosed subacromial impingement syndrome were included in the study. We evaluated the quality of life of the patients with subacromial impingement syndrome using the Shoulder Disability Questionnaire (SDQ), Quick Disabilities of the Arm, Shoulder and Hand Score (QDASH), Visual analog Scale(VAS), University of California at Los Angeles (UCLA) shoulder scores. Mental component score and physical component score were measured using SF-36 in the assesment of the quality of life and different scores were evaluated. The indirect and direct effects of these tests on the quality of life were examined in a single model using the structural equation modelling.
\end{abstract}

Results: The most total effect on PCS was SDQ, and the QDASH variable had the least total effect on PCS. Considering the results of MCS, the most total effect was the PCS, and VAS had the the minimum total effect.

Conclusion: The quality of life of the patients with subacromial impingement syndrom give more detailed informations when analysing the scores dependently. Evaluating the quality of life of subacromial impingement syndrome, using different measures of patients dependently will provide a more detailed research opportunity. If the patient quality of life evaluation is done in detail, it will facilitate the selection of appropriate treatment.

Keywords: Quality of life, statistics, assessment, structural equation modelling
Öz

Amaç: Farklı parametreler kullanarak subakromiyal sendromlu hastaların yaşam kalitesini aynı anda tek bir modelde değerlendirmektir.

Gereç ve Yöntem: Çalışmaya subakromiyal sıkışma sendromu tanısı alan 90 hasta dahil edildi. Subakromiyal sıkışma sendromu olan hastaların yaşam kaliteleri Omuz Engellilik Anketi (SDQ), Kol, Omuz ve El Sorunları Hızlı Anketi, (QDASH), Görsel Analog Skala (VAS), UCLA omuz skorları ile değerlendirdik. Yaşam kalitesi değerlendirmesinde Zihinsel bileşen puanı ve fiziksel bileşen puanı SF-36 kullanılarak ölçüldü ve farklı ölçek parametreleri değerlendirildi. Bu testlerin yaşam kalitesine dolaylı ve doğrudan etkileri yapısal eşitlik modeli kullanılarak tek bir modelde incelenmiştir.

Bulgular: PCS üzerindeki en büyük toplam etki SDQ değişkenine ait iken QDASH en az toplam etkiye sahipti. MCS'nin sonuçları dikkate alındığında, en büyük toplam etki PCS'ye ait iken, VAS minimum toplam etkiye sahipti.

Sonuç: Subakromiyal sıkışma sendromlu hastaların yaşam kalitesinin değerlendirilmesinde, farklı parametrelerin bağımlı olarak analiz edilmesi daha detaylı bilgi sağlanmaktadır. Yaşam kalitesinin değerlendirilmesinde, hastaların farklı ölçüm değişkenleri arasındaki ilişkilerin incelenmesi ve bağlantılandırılması detaylı araştırma fırsatı sağlamaktadır. Hasta yaşam kalitesi değerlendirmesinin detaylı bir şekilde yapılması uygun tedavi seçimini kolaylaştıracaktır.

Anahtar Kelimeler: Yaşam kalitesi, istatistik, değerlendirme, yapısa eşitlik modellemesi 


\section{INTRODUCTION}

Subacromial impingement syndrome (SAIS), which encompasses a spectrum of subacromial space pathologies including partial thickness rotator cuff tears, rotator cuff tendinosis, calcific tendinitis, and subacromial bursitis is one of the common causes of shoulder pain, and mainly results with functional loss and disability. ${ }^{[1]}$

The syndrome may be detected in any age, and sex. Shoulder problems affect the general health of the individual. It is important to evaluate the quality of life, and treatment results of patients with subacromial impingement syndrome. The main methods used in the evaluation of the results were the scores of The University of California and Los Angeles shoulder score (UCLA) and American Shoulder and Elbow Surgeons (ASES). The evaluation of the methods were different. Therefore, various methods have been developed in recent years, and the validity and reliability studies were conducted. There is an increasing interest on these studies. The results were required to be used in a coordinated manner because the scores varied. General health of the patients needs to be assessed in addition to assessing the adequacy of the shoulder. There are limited number of studies which used the SF-36 scale in evaluation of the quality of life of SAIS patients. [2-10]

We evaluated the quality of life of the patients with subacromial impingement syndrome using the Shoulder Disability Questionnaire (SDQ), Quick Disabilities of the Arm, Shoulder and Hand Score (QDASH), Visual analog Scale (VAS), UCLA shoulder scores simultaneously in the present study.

\section{MATERIAL AND METHOD}

The study was conducted with patients who presented with shoulder pain to Physical Medicine and Rehabilitation Polyclinic in Duzce University at least for three months without any major trauma. The permissions, and ethic committee approval were obtained by the Research Ethics Committee of the Medical Faculty, Duzce University and informed consent was taken from patients. Patients were applied to polyclinic between september 2015 and september 2016. For patients the detailed physical examination was performed. Manual muscle strength and speed test, Hawkins test, neer compression test, Jobe test, painful arch test, Geezest test were evaluated, and in addition shoulder joint range of motion measured by a standardized goniometer was also evaluated. The routine blood tests(complete blood count, CRP, RF, sedimentation, biochemistry) were studied after the detailed anamnesis, and physical examinations. The PA chest radiography, four-way cervical graph, shoulder graph for both shoulders(anteroposterior, lateral, outlet, axillary), and the magnetic resonance imaging (MRI) of the affected shoulder were taken. The diagnosis of SAIS was made with the help of the clinical, and MRI information. Patients in stage one, and stage three were excluded from the study. 90 patients with fibrosis, and tendinitis were included in the study. All patients in the study were in stage 2 . The age, sex, profession, affected parts of the patients were recorded.

Clinical Measure: VAS was used in the evaluation of the severity of pain. SDQ, QDASH and UCLA scores were used in the evaluation of the shoulder functions. The overall quality of life was evaluated using the Short Form 36 (SF-36).

VAS: VAS is a quick, and easy- to use scale used in assessing the pain, disability, and functionality. The meanings of the figures on $10-\mathrm{cm}$ horizontal line were explained to the patients. 0 indicated no pain, however 10 indicated the most severe pain, and 5 indicated the moderate pain. ${ }^{[11]}$

QDASH: DASH scoring evaluates the difficulty in performing 30 different activities related to the upper limb in daily life. We used the QDASH scoring in our study which was based on the selection of 11 of the most used activities. We used the first part of the tests considering the demographics of the patient group. Each question was evaluated in 5 levels. The ability to do the activity with no difficulty scored 1 point, however the inability to do the activity scored 5 points. Each section scored between 0-100. High scores referred to high disability level. ${ }^{[1]]}$

UCLA: A total of 35 points were evaluated for pain, function, patient satisfaction, flexion strength, and flexion. Each pain, and function scored from 1 to 10, and the active flexion angle, flexion muscle strength, and patient satisfaction were 1-5 points. The total score of 34-35 was regarded excellent, 29-33 as good, and 29 points as weak..$^{[1]}$

SDQ: SDQ is a questionnaire consisting of 16 items related with pain describing situations that increase symptoms in shoulder patients. It is used in the evaluation of the shoulder function. The patients responded by marking each item as yes or no according to whether they performed the items in the last 24 hours. If the activity was painful the answer would be yes and, if the activity caused no pain the answer would be no, inapplicable referred that the activity was not performed within the last 24 hours. 100 indicated maximum sickness, and the point 0 indicated the maximum health. ${ }^{[1]}$

SF-36: It is a generic measure of reliability, and validity in patients with musculoskeletal disorders, consisting of a total of 36 items. These 36 items cover 8 different health related dimensions, which are physical functioning, social functioning, mental health, vitality, physical role, emotional role, bodily pain, and general health. Eight subscales are grouped under the physical component score (PCS), and mental health score (MCS). SF 36 also inquires about the negative status as well as the positive health status. The scale evaluates the last 4 weeks. The scores obtained from the items are coded, and converted into a scaled scale from 0 (worst case) to 100 (best case) for each dimension. ${ }^{[11]}$

\section{Statistical Analysis}

The descriptive statistics of the numeric variables were given as mean, median, standard deviation, minimum and maximum. SF-36, SDQ, VAS, QDASH, and UCLA scores were calculated. The correlations between the scores were assessed 
by the Pearson's correlation coefficient. A multivariate analysis method of structural equation modelling was used in evaluating the scores. The indirect, and direct effects of the scores which might be effective for SF-36 were calculated as a result of the regression analysis. The fitted model was evaluated with Chi-Square goodness of fit test. RMSEA, $\mathrm{GFI}, \mathrm{AGFI}, \mathrm{NFI}, \mathrm{RFI}$, and CFI were taken as the criteria in the evaluation of the model fit. All statistical tests were performed at a significance level of $p<0.05$. Calculations were made using the Statistical Package for the Social Sciences(SPSS) (version 21), and Analysis of Moment Structures (AMOS) (version 24) programs.

Table 1.Descriptive statistics of the variables

\begin{tabular}{lccccc} 
& Mean & Median & $\begin{array}{c}\text { Std. } \\
\text { Deviation }\end{array}$ & Minimum & Maximum \\
\hline Age & 52.05 & 53.00 & 10.057 & 28.00 & 72.00 \\
SDQ & 79.90 & 86.60 & 17.984 & 33.30 & 100.00 \\
UCLA & 15.51 & 15.00 & 4.120 & 2.25 & 23.00 \\
QDASH & 78.22 & 77.25 & 7.296 & 59.10 & 95.50 \\
VAS & 4.90 & 5.00 & 0.671 & 3.00 & 6.00 \\
PCS & 31.47 & 32.50 & 9.631 & 11.25 & 47.50 \\
MCS & 45.33 & 44.73 & 12.024 & 19.50 & 73.25 \\
\hline
\end{tabular}

Table 2. Pearson's correlation coefficients between the scores

\begin{tabular}{|c|c|c|c|c|c|c|}
\hline & & SDQ & UCLA & QDASH & PCS & MCS \\
\hline \multirow{3}{*}{ VAS } & $\begin{array}{l}\text { Pearson's } \\
\text { Correlation }\end{array}$ & 0.297 & -0.035 & -0.038 & -0.168 & -0.078 \\
\hline & $p$ & 0.005 & 0.744 & 0.724 & 0.113 & 0.465 \\
\hline & $\mathrm{N}$ & 90 & 90 & 90 & 90 & 90 \\
\hline \multirow{3}{*}{ SDQ } & $\begin{array}{l}\text { Pearson's } \\
\text { Correlation }\end{array}$ & 1 & -0.259 & -0.043 & -0.369 & -0.196 \\
\hline & $p$ & & 0.014 & 0.690 & $<0.001$ & 0.065 \\
\hline & $\mathrm{N}$ & 90 & 90 & 90 & 90 & 90 \\
\hline \multirow{3}{*}{ UCLA } & $\begin{array}{l}\text { Pearson's } \\
\text { Correlation }\end{array}$ & -0.259 & 1 & 0.132 & 0.279 & 0.220 \\
\hline & $p$ & 0.014 & & 0.214 & 0.008 & 0.037 \\
\hline & $\mathrm{N}$ & 90 & 90 & 90 & 90 & 90 \\
\hline \multirow{3}{*}{ QDASH } & $\begin{array}{l}\text { Pearson's } \\
\text { Correlation }\end{array}$ & -0.043 & 0.132 & 1 & 0.002 & 0.227 \\
\hline & $p$ & 0.690 & 0.214 & & 0.984 & 0.031 \\
\hline & $\mathrm{N}$ & 90 & 90 & 90 & 90 & 90 \\
\hline \multirow{3}{*}{ PCS } & $\begin{array}{l}\text { Pearson's } \\
\text { Correlation }\end{array}$ & -0.369 & 0.279 & 0.002 & 1 & 0.480 \\
\hline & $p$ & $<0.001$ & 0.008 & 0.984 & & $<0.001$ \\
\hline & $\mathrm{N}$ & 90 & 90 & 90 & 90 & 90 \\
\hline \multirow{3}{*}{ MCS } & $\begin{array}{l}\text { Pearson's } \\
\text { Correlation }\end{array}$ & -0.196 & 0.220 & 0.227 & 0.480 & 1 \\
\hline & $\mathrm{p}$ & 0.065 & 0.037 & 0.031 & $<0.001$ & \\
\hline & $\mathrm{N}$ & 90 & 90 & 90 & 90 & 90 \\
\hline
\end{tabular}

\section{RESULTS}

Ninety patients diagnosed with subacromial impingement syndrome included 37 men (41.1\%), and 53 women (58.9\%), and the mean age was $52.05 \pm 10.05$ years. The descriptive statistics of SDQ, UCLA, QDASH, VAS, MCS, and PCS are given in Table 1.

Significant positive correlations were found between MCS, and UCLA and DASH scores (respectively p:0.037; p:0.031), however there was no statistically significant relationship between SDQ, and MCS scores (p:0.065) in examination of the correlations between SDQ, UCLA, DASH, VAS, and SF36 scores. The results of the relationships between PCS and scores showed that, PCS had significant relationship with SDQ, UCLA and MCS (respectively $p<0.001 ; p: 0.008 ; p<0.001$ ). While there was a relationship with SDQ in the negative direction, a positive relationship was detected between UCLA, and MCS (Table 2).

The results, and the final model are given in Figure 1, Table 3, and Table 4 by the structural equation modelling. The relations between the parameters in the model were examined at the same time using a single model. The model was formed by considering the relations between MCS, and PCS. It was concluded that the model obtained as a model of structural equilibrium was an acceptable model ( $p>0.05, c M i N / D F: 0.300$, RMSEA $<0.001$ (absolute fit measures)). Incremental fit measures were GFI:0.991, AGFI:0.977,CFI:1.000,RFI:0.929. Parsimonious fit measures were obtained as PNFI:0.513, PCFI:0.533 (Figure 1, Table 3, Table 4).

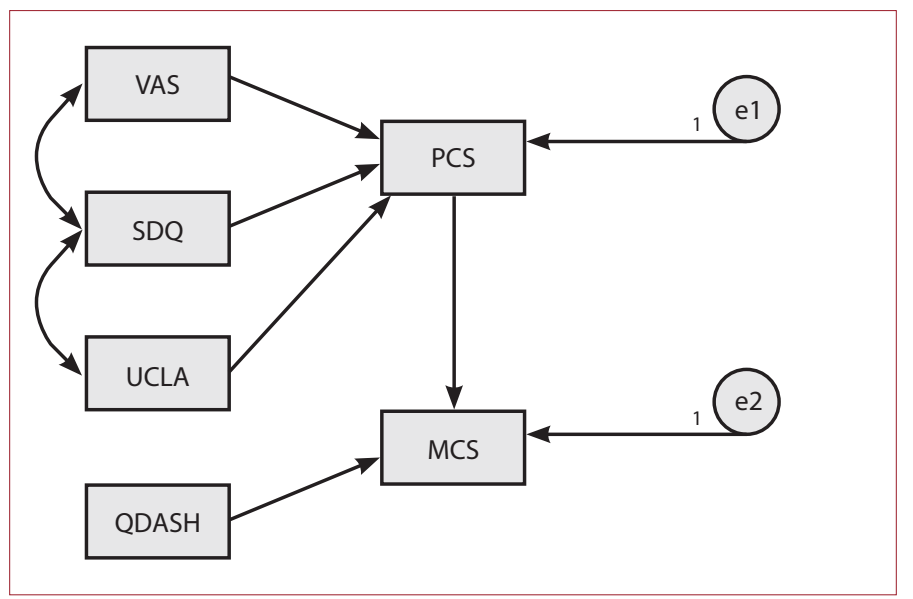

Figure 1. Final model of the structural equation model

\begin{tabular}{cccccccc} 
& & & Estimate & Standardized Estimates & Standard Error & Composite Reliability & p \\
\hline PCS & $<---$ & UCLA & 0.467 & 0.200 & 0.233 & 0.045 & -2.007 \\
PCS & $<---$ & SDQ & -0.158 & -0.295 & 0.056 & -2.836 & 0.005 \\
PCS & $<---$ & VAS & -1.054 & -0.074 & 1.445 & 0.729 & 0.466 \\
MCS & $<---$ & QDASH & 0.372 & 0.226 & 0.148 & 0.012 & 2.515 \\
MCS & $<---$ & PCS & 0.599 & 0.479 & 0.112 & 5.329 & $<0.001$ \\
\hline
\end{tabular}


The standardized, and unstandardized regression coefficients obtained as a result of the structural equation model are given together with the standard errors, and $p$ values in Table 4. PCS has a directly positive relationship with UCLA (beta:0.467; $\mathrm{p}: 0.045)$. There was a direct negative correlation between PCS, and SDQ (beta: $-0.158 ; \mathrm{p}: 0.005)$. A direct positive correlation between MCS, and QDASH(beta:0.372; p:0.012) was detected in evaluation of the relationship with MCS. There was no statistically significant relationship between VAS, and PCS ( $p>0.05$ ) (Table 3).

The indirect, and direct effect values of independent variables are given in Table 4. It was observed in examination of the results that SDQ had the most total effect on PCS, and the QDASH variable had the least total effect on PCS. PCS was found to have the maximum total effect in evaluation of the results for MCS, and VAS had the the minimum total effect.

\begin{tabular}{llccccc}
\hline \multicolumn{6}{c}{ Table 4. Total, direct, indirect effects of independent variables } \\
\hline \multirow{4}{*}{ PCS } & Effect & VAS & SDQ & QDASH & UCLA & PCS \\
\hline \multirow{4}{*}{ MCS } & Total & -0.074 & -0.295 & 0.000 & 0.2 & 0.000 \\
& Direct & -1.054 & -0.158 & 0.000 & 0.467 & 0.000 \\
& Indirect & 0.000 & 0.000 & 0.000 & 0.000 & 0.000 \\
& Total & -0.035 & -0.142 & 0.226 & 0.096 & 0.479 \\
& Direct & 0.000 & 0.000 & 0.372 & 0.000 & 0.599 \\
& Indirect & -0.631 & -0.095 & 0.000 & 0.280 & 0.000 \\
\hline
\end{tabular}

\section{DISCUSSION}

Subacromial impingement syndrome is a current common pathology. The main causes of shoulder pain are the waist, and neck pains. However, subacromial impingement syndrome became the third cause of pain..$^{[9]}$ Patients with subacromial impingement syndrome have significantly lower quality of life than the general population. The quality of life of these patients is very important in treatment. Therefore, we wanted to evalute the quality of life of these patients by combining the scores in the present study. We believe that only the measurement of the SF-36 was not adequate for evaluation as the other scores also affected the quality. In addition, it should be born in mind that there was an association between the scores, and it would not be right to evaluate each score separately. Therefore, we evaluated SDQ, QDASH, UCLA, and VAS scores (independent scores) which might affect the subacromial impingement syndrome patients, in addition to the score of the quality of life. The relationships between these independent scores were also evaluated. The evaluation of the results showed that the most total effect on PCS was SDQ variable, and the QDASH variable had the least total effect on PCS. Considering the results of MCS, the most total effect was the PCS, and VAS had the the minimum total effect. There was a direct positive correlation between PCS and UCLA, a direct negative correlation between PCS and $\mathrm{SDQ}$. Also, there was a direct positive correlation between MCS and QDASH.
Although there is no information whether women or men are more affected by the disease in the subacromial impingement syndrome, the number of affected women were found higher in the studies because mostly the women presented to hospital with pain. Consistent with most of the studies in the literature, $58.9 \%$ of the patients were female. ${ }^{[10,12,13]}$ Researchers in some studies divided patients into groups in accordance with the stages on the subacromial impingement syndrome, however, the others divided patients into randomised groups. ${ }^{[14-17]}$ Therefore, we included the patients with stage 2 subacromial impingement syndrome in the present study. Researchers may evaluate the patients in different stages in the further studies.

\section{CONCLUSIONS}

This study evaluate the subacromial impingement syndrome patients quality of life with a structural equation modelling. Also for evaluation the quality of life, the interaction of other scores (tests) were considered. Evaluation of quality of life in SAIS patients by considering possible relations among functions with a hypothetical model, give more accurate results to clinicians and nurses. Also in our study, statistical analysis was a multivariate method and in the structural equation model we use a path diagram to use all the relations of score. We think that this is the first study that evaluate this parameters in a single model for subacromial impingement syndrome. Appropriate treatments can be given for subacromial impingement syndrome patients when the quality of life evaluated correctly and dependently with the other measures. If the patient quality of life evaluation is done in detail, it will facilitate the selection of appropriate treatment.

Main points: The quality of life of the patients with subacromial impingement syndrom give more detailed informations when analysing the scores dependently.

The quality of life measures have direct and indirect effects with each other.

For subacromial impingement syndrome patients' assessment of quality of life is very important issue.

The most total effect on PCS was SDQ variable, and the QDASH variable had the least total effect on PCS.

The most total effect on MCS was the PCS, and VAS had the least total effect on MCS.

\section{ETHICAL DECLARATIONS}

Ethics Committee Approval: The permissions, and ethic committee approval were obtained by the Research Ethics Committee of the Medical Faculty, Duzce University.

Informed Consent: Written consent was obtained from all patients who participated in the study and their relatives.

Referee Evaluation Process: Externally peer-reviewed.

Conflict of Interest Statement: The author(s) declared no potential conflicts of interest with respect to the research, authorship, and/or publication of this article. 
Financial Disclosure: This study was supported by Duzce University Research Fund (Project Number: 2015/183).

\section{REFERENCES}

1. Umer M ,Qadir I, Azam M. Subacromial Impingement Syndrome. Orthopedic reviews 2012;4(2):e18.

2. Fu FH, Harner $C D$, Klein $A H$. Shoulder impingement syndrome. A critical review. Clin Orthop 1991;269:162-73.

3. Mantone JK, Burkhead WZ Jr, Noonan J Jr. Nonoperative treatment of rotator cuff tears. Orthop Clin North Am 2000;31: 295-311.

4. Morrison DS, Greenbaum BS, Einhorn A. Shoulder impingement. Orthop Clin North Am 2000;31(2): 285-93.

5. Morrison DS, Frogameni AD, Woodworth P. Non-operative treatment of subacromial impingement syndrome. J Bone Joint Surg Am 1997;79(5):732-7.

6. Beaton DE, Richards RR.Measuring function of the shoulder. A crosssectional comparison of five questionnaires. J Bone Joint Surg Am 1996;78(6):882-90.

7. Dawson J, Fitzpatrick R, Carr A. Questionnaire on the perceptions of patients about shoulder surgery. J Bone Joint Surg Br 1996;78(4):593-600.

8. Ozcan A, Z Tulum, Bacakoglu AK. The relationship between quality of life and functional status measurements in shoulder impingement syndrome. Acta Orthop Traumatol Turc 2003;37(3):219-25.

9. Michener LA, McClure PW, Karduna AR. Anatomical and biomechanical mechanisms of subacromial impingement syndrome. Clin Biomech 2013;18(5):369-79.

10. Çalış M. Diagnostic values of clinical diagnostic tests in subacromial impingement syndrome. Ann Rheum Dis 2000; 59(1):44-47.

11. Pasin T. Subakromial sıkışma sendromu tedavisinde PRP enjeksiyonu, kortikostreoid enjeksiyonu ve fizik tedavinin etkinliğinini karşılaştırılması. Uzmanlık tezi. Düzce Üniversitesi Tıp Fakültesi.2017.

12. Lomberdi Jr.l, Magri AG, Fleury AM et al. Progressive resistance training in patients with shoulder impingement syndrome: A Randomized Controlled Trial. Arthritis Rheum 2008; 59(5):615-622.

13. Haahr JP, Ostergaard S, Dalsgaard J et al. Exercises Versus arthroscopic decompression in patients with subacromial impingement: A randomised, controlled study in 90 cases with a one year follow up. Ann Rheum Dis 2005;64(5):760-764.

14. Frieman B.G., Albert T.J.Rotator cuff disease:A review of diagnosis, pathophysiology and current trends in treatment. Arch Phys Med Rehabil 1994;75(5):604-609.

15. Aktaş I, Akgün K, Çakmak B. Therapeutic effect of pulsed electromagnetic field in conservative treatment of subacromial impingement syndrome. Clin Rheumatol 2007;26(8):1234-1239.

16. Yelkovan M, Eskiyurt N, Öncel A et al. Magnetic field therapy in the treatment of subacromial impingement syndrome. Journal of Istanbul Faculty of Medicine 2006;69(2):36-40.

17. Celik D, Akyuz G, Yeldan I. Comparison of the effects of two different exercise programs on pain in subacromial impingement syndrome. Acta Orthop Traumatol Turc 2009;43(6):504-509. 